\title{
Effect of entrepreneurship education on MBA students in Kerala on their entrepreneurial intent with special reference to the students of Mahatma Gandhi University, Kottayam, Kerala
}

\author{
Muhammed Sajjad. A, Sathyapriya. J
}

\begin{abstract}
The positive effect of entrepreneurship education on entrepreneurship has been proved world over and along with the developed world, developing world also is increasingly giving importance to entrepreneurship education. This is an empirical study about the effects of an entrepreneurship course on final semester MBA students of MG University Kerala. The descriptive research used convenience sampling. A questionnaire containing 50 close ended multiple choice questions and one open ended questions were used to obtain responses from 132 Semester Four MBA students from various Institutions under MG University in Ernakulam District, Kerala. The study found that the majority of MBA students prefer high paying job over starting their own business. But the entrepreneurial traits like risk taking, problem solving, decision making etc., which they studied as part of the entrepreneurship course will definitely help them in their future career prospects. The entrepreneurship course offered to MBA students in Kerala need revamping and new innovative training methods need to be introduced to create an entrepreneurial culture among MBA students
\end{abstract}

Key words: business, entrepreneurship, risk taking, training

\section{INTRODUCTION}

The positive effect of entrepreneurship education on entrepreneurship has been proved world over and along with the developed world, developing world also is increasingly giving importance to entrepreneurship education. The government has realised that entrepreneurship is the main mechanism to provide large scale employment as well as for capital formation. Realising its importance, the national and state Governments of India are initiating policies and programmes to promote entrepreneurship and self-employment to foster economic development (Ahluvalia, 2005). But most of the population are not having an entrepreneurial culture or are not oriented towards it. So educating potential entrepreneurs about entrepreneurship has become necessary to achieve the objectives of the state (Barot, 2015). Most of the developing countries including India have started specialised institutes to train as well as promote entrepreneurs. Many nations have already included entrepreneurship as a subject in their University curriculum. In a survey on international MBA students in UK about the effectiveness of entrepreneurship education in meeting the motivations and expectations, majority of them responded that career development is a major motivator.
Revised Manuscript Received on July 05, 2019.

Muhammed Sajjad. A, Department of Management Studies, Periyar Maniammai Institute of Science \& Technology, Thanjavur, India.

Sathyapriya J, Department of Management Studies, Periyar Maniammai Institute of Science \& Technology, Thanjavur, India.

They felt that they had gained significant learning, personality development and confidence to achieve their goals from the entrepreneurship module (David Rae, 2012) The Universities in Kerala also have included entrepreneurship as a subject in their Undergraduate courses like BCom and BBA and post graduate business courses like MBA. The MBA students of MG University study the subject, "Entrepreneurship and Project Management" in their second semester. This is a study to find out the effectiveness of entrepreneurship education on MBA students regarding their intention to start an enterprise rather than go for employment after their studies.

\section{LITERATURE REVIEW}

Many studies had been conducted in the developed and developing world about the effects of entrepreneurship course on business students. Some studies conducted on business students including MBAs and its results are mentioned here. In a research about the impact of entrepreneurship education on students in the higher education institutions (HEIs) in France, Germany and Poland, while the enterprise education has a favourable impact on the entrepreneurial attitude of French and Polish students, it was negative for German students. It was also found out that the impact is more significant in male students (Gary Packham, 2010). In a study that explores the learning experiences of 60 post graduate international students who had completed the entrepreneurship programme at the University of Lincoln, $\mathrm{UK}$, it was found out that EEE has a wider influence on personal development and career planning than the intention to create new ventures (David Rae, 2013). A study to find out the effectiveness of entrepreneurship education given to third level students of Northern Ireland by NICENT, it was found that they were able to increase the interest and positive attitude entrepreneurship (Hegarty, 2006). 
A case study to analyse the effectiveness of entrepreneurship training given to the post graduate students in Portugal by concentrating on number firms created and industries chosen by individuals, results show a success rate of $41 \%$ (Carvalho, 2009). A survey of 138 graduate students enrolled in a part time MBA course at a large mid-western University in US, suggests relationship between self- efficacy, perceived skills, and abilities to manage a new venture and entrepreneurial intentions to start a new venture (Gerba, 2012). In a survey conducted on students from major public and private Universities in Malaysia, the results showed that specialised entrepreneurship education (SEE) results in increased entrepreneurial self-efficacy and promote self-employment intention and employability value (Rejab, 2010). A study conducted on polish students undergoing "Starting a New Enterprise (SANE)" course found that they had limited prior entrepreneurial experiences and expectations and liked the course. Thus entrepreneurial training informs the entrepreneurial intent and career aspirations (Paul Jones, 2008). A research to find the effectiveness of Basic Student Entrepreneurship Programme (BSEP) among local University graduates in Malaysia found out that the course had developed intention towards becoming agri-entrepreneurs (Zainalabidin Mohamed, 2012).

To understand how entrepreneurship is integrated in the business school curricula of the top business schools in India, a study show that entrepreneurship still has a long way to go in terms of earning the status of a preferred course among management students in India (Basu, 2014). A case study to determine entrepreneurial characteristics among business students and examine the influence of demographic factors on the entrepreneurial characteristics of the students finds that the student's academic marks and father/ guardian's occupation have little influence on their entrepreneurial characteristics (Sahasranam, 2009). A study was conducted to find out the factors of entrepreneurial orientation among the management students on a sample of 200 final-year postgraduate management students from leading management institutes in Warangal region (Andhra Pradesh, India). Some of the important factors needed to be an entrepreneur emerged from the study are resourcefulness, future orientation, competence, self-appraisal, need for recognition, independence, societal wellbeing, goal-oriented and self-confidence (Purna Prabhakar Nandamuri, 2012). Another Case study attempts to understand the idea of having apprenticeship in entrepreneurship courses in our professional colleges and explore the option of Apprenticeship under a successful entrepreneur(s). MBA students of the Osmania University, Hyderabad were studied and majority of the student respondents, in particular male students have shown an inclination towards entrepreneurship as a career option, while only a few female students have responded positively (K.G.Chandrika, 2012).

\section{METHODOLOGY}

A questionnaire about entrepreneurship education and its effect were developed and distributed to the final semester students of MG University, one of the leading Government universities in Kerala state. 132 valid questionnaires were received from MBA students of different affiliated colleges of MG University in Ernakulam District of Kerala State. Convenience sampling was used for the descriptive research to collect the data. 50 close ended multiple choice questions and one open ended question were used to get the response of the students. The questionnaire were pre-tested to make it error free. The questions were designed in such a way that they had elicited information about the student before the training, during the training and after the course from the respondents that was the final semester MBA students of MG University. Percentage analysis was done to analyze data and Chi-square test were also done to validate the results

\section{ANALYSIS AND INTERPRETATION}

A Brief Description about the Subject- Entrepreneurship and Project Management: Mahatma Gandhi University, Kottayam, Kerala had introduced the subject on entrepreneurship as a core course in the Second semester MBA from the year 2017 onwards. It was a five module course which should be finished within 60 instructional hours including evaluation. The objectives of the course was to provide the participants a basic understanding about entrepreneurship, the role of small business in an economy and to impart necessary knowledge and skills for project formulation and project management relevant for business. The first module covers entrepreneur, entrepreneurship, innovation, role of entrepreneurship in economic development etc. The second module covers identification and screening of project ideas, various analysis, plant lay-outs etc. The third module covers concept of the project, project formulation etc. The fourth module covers Project planning, scheduling, MS projects etc. The fifth module covers project implementation, project management organization etc. [16]

B Demographic Analysis: Majority (85\%) of the students who responded were in the age group 21-23 years and $15 \%$ of the respondents in the age group 23-25 years. Female students constitute $73 \%$ and males $27 \%$. Most of the $(79 \%)$ of the respondents were having family income less than Rs. 5 lakh per year and $21 \%$ were having income Rs.5-10 Lakh. Regarding occupation of the parent, $30 \%$ of the student's parents were having business, $30 \%$ were having job, $34 \%$ of the parents of the respondents were self-employed and $6 \%$ in other occupations like farming etc. Only $15 \%$ of the respondents had previous job experience while $12 \%$ had previous business experience. About reasons for joining the MBA course, $74 \%$ preferred high paying job and $21 \%$ wanted to start enterprises, $1 \%$ wanted to join family business and $3 \%$ 392

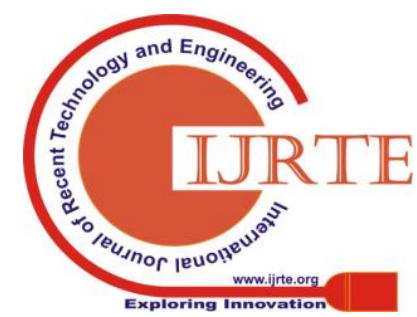


wanted to pursue some other profession. Regarding education background, $48 \%$ of the respondents were with BCom as degree, $28 \%$ with BBA, $9 \%$ with BSC, $6 \%$ with BA, $3 \%$ with BTech and $6 \%$ with other UG/PG backgrounds. Table No.1 show the demographic analysis of respondents.

Table No.1 Demographic details

\begin{tabular}{|c|c|c|c|}
\hline Variable & Sub-variable & Response & $\begin{array}{c}\text { Percent } \\
\text { age }\end{array}$ \\
\hline \multirow[t]{2}{*}{ Age } & $21-23$ years & 112 & 85 \\
\hline & $23-25$ & 20 & 15 \\
\hline \multirow[t]{2}{*}{ Gender } & Male & 36 & 27 \\
\hline & Female & 96 & 73 \\
\hline \multirow[t]{2}{*}{$\begin{array}{l}\text { Family } \\
\text { Income }\end{array}$} & $\begin{array}{l}\text { Less Than } \\
\text { Rs. } 5 \text { Lakhs }\end{array}$ & 104 & 79 \\
\hline & 5-10 Lakhs & 28 & 21 \\
\hline \multirow{4}{*}{$\begin{array}{l}\text { Parent's } \\
\text { Occupation }\end{array}$} & Job & 40 & 30 \\
\hline & $\begin{array}{c}\text { Self } \\
\text { Employed }\end{array}$ & 44 & 34 \\
\hline & Business & 40 & 30 \\
\hline & Others & 4 & 3 \\
\hline $\begin{array}{l}\text { Previous job } \\
\text { experience }\end{array}$ & & 20 & 15 \\
\hline $\begin{array}{l}\text { Previous } \\
\text { Business } \\
\text { Exp. }\end{array}$ & & 16 & 12 \\
\hline \multirow{4}{*}{$\begin{array}{ll}\text { Reasons for } \\
\text { Joining } & \\
\text { MBA } & \end{array}$} & $\begin{array}{l}\text { High Pay } \\
\text { job }\end{array}$ & 98 & 75 \\
\hline & $\begin{array}{c}\text { Start } \\
\text { Business }\end{array}$ & 28 & 21 \\
\hline & $\begin{array}{c}\text { Join Family } \\
\text { Business }\end{array}$ & 2 & 1 \\
\hline & Others & 4 & 3 \\
\hline \multirow{2}{*}{$\begin{array}{l}\text { Degree } \\
\text { Background }\end{array}$} & B.Com & 64 & 48 \\
\hline & $\mathrm{BBA}$ & 36 & 28 \\
\hline
\end{tabular}

\begin{tabular}{|c|c|c|c|}
\hline & B.Tech & 4 & 3 \\
\cline { 2 - 4 } & BSc & 12 & 9 \\
\cline { 2 - 4 } & BA & 8 & 6 \\
\hline & Others & 8 & 6 \\
\hline
\end{tabular}

$C$ Overview of entrepreneurship related activities during the MBA course: All of the respondents had Industrial Visits and Organization study during the MBA course. $82 \%$ of the respondents felt that their understanding about the functioning of the industry had increased after the visit. $70 \%$ of the respondents had interaction with industry experts and majority of them felt that it was fruitful. $64 \%$ of the students polled had attended entrepreneurship/ start up workshops conducted by outside agencies and $71 \%$ among them felt that it was helpful in understanding entrepreneurship. $79 \%$ had responded that their college had an entrepreneurship development cell $15 \%$ were members of the cell and only $41 \%$ are satisfied with the working of the cell.

D Feedback about the entrepreneurship course taught in the Second semester: Regarding teaching of entrepreneurial skills, $76 \%$ had responded that entrepreneurship skills were taught as part of the course. Of the $76 \%$ of respondents, $27 \%$ had agreed strongly that the skills were taught to their satisfaction. But $9 \%$ were neutral, $12 \%$ disagreed and $3 \%$ had strongly disagreed to the question. Table No.2 Shows the response of the students.

Table No. 2 Taught about Entrepreneurship Skills

\begin{tabular}{|l|l|l|}
\hline Response & Frequency & Percentage \\
\hline Strongly Agree & 36 & 27 \\
\hline Agree & 64 & 49 \\
\hline Neutral & 12 & 9 \\
\hline Disagree & 16 & 12 \\
\hline Strongly Disagree & 4 & 3 \\
\hline Total & 132 & 100 \\
\hline
\end{tabular}

Regarding knowledge about starting a business, 73\% had agreed that they had learned about how to start a business, $67 \%$ about identification and screening of business ideas, $51 \%$ got the knowledge about financial/marketing/technical analysis, $73 \%$ knew about how to prepare a business plan/ project report, $55 \%$ learned about project planning and implementation and $58 \%$ had responded that they had studied about Government regulations, various incentive

\section{Published By:}

Blue Eyes Intelligence Engineering \& Sciences Publication

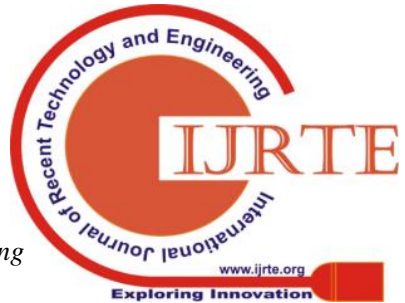


Effect of Entrepreneurship Education on MBA students in Kerala on their entrepreneurial intent with special reference to the students of Mahatma Gandhi University, Kottayam, Kerala

schemes and subsidies for new enterprises.

Regarding teaching methodology, $50 \%$ responded that they had attended Lecture on the subject, $21 \%$ participated in class room discussions on the topic, $15 \%$ had conducted seminars on the subject, and $7 \%$ participated in case analysis and $7 \%$ had participated in role plays. So, traditional teaching methods like lecture by the faculty were still the popular methodology in the University. Table No.3 shows the response of students to different teaching methodologies

Table No. 3 Teaching Methodology used in the class

\begin{tabular}{|l|l|l|}
\hline Methodology & Frequency & Percentage \\
\hline Lecture & 108 & 50 \\
\hline Class Discussion & 44 & 21 \\
\hline Case Analysis & 16 & 7 \\
\hline Role Play & 16 & 7 \\
\hline Seminar & 32 & 15 \\
\hline Total & 216 & 100 \\
\hline
\end{tabular}

Regarding the classes on the entrepreneurship course, $63 \%$ of the students had responded that the classes were interesting, $60 \%$ felt that the topics covered were relevant for the skills required, $70 \%$ agreed that the faculty was able to clear their doubts, only $40 \%$ felt that the course materials/texts given were sufficient to understand the course and $52 \%$ of the respondents were of the opinion that the class room were attractive and functional.

Regarding evaluation of the course, $42 \%$ had attended class tests, $37 \%$ had submitted assignments, $9 \%$ had participated in case analysis and $12 \%$ had attended attitude surveys as part of evaluation of the subject. Table No. 4 describes the evaluation details of the course.

Table No. 4 Evaluation details

\begin{tabular}{|l|l|l|}
\hline Evaluation & Frequency & Percentage \\
\hline Test & 72 & 42 \\
\hline Assignment & 64 & 37 \\
\hline Case Study & 16 & 9 \\
\hline Interview & 0 & 0 \\
\hline Attitude Survey & 20 & 12 \\
\hline
\end{tabular}

\begin{tabular}{|l|l|l|}
\hline Ratings & 0 & 0 \\
\hline Total & 172 & 100 \\
\hline
\end{tabular}

About feedback taken at the end of the course, $42 \%$ had responded affirmatively about feedback taken at the end of the entrepreneurship course. $64 \%$ of the respondents were satisfied out of which $12 \%$ were highly satisfied with course, $30 \%$ were neutral in their opinion, $3 \%$ were dissatisfied and $3 \%$ highly dissatisfied with the present course. Majority $(81 \%)$ felt that the present course required improvement. Table No.5 shows the satisfaction level of respondents to the course on entrepreneurship.

Table No. 5 Satisfaction with the course on entrepreneurship

\begin{tabular}{|l|l|l|}
\hline Response & Frequency & Percentage \\
\hline Highly Satisfied & 16 & 12 \\
\hline Satisfied & 68 & 52 \\
\hline Neutral & 40 & 30 \\
\hline Dissatisfied & 4 & 3 \\
\hline Highly Dissatisfied & 4 & 3 \\
\hline Total & 132 & 100 \\
\hline
\end{tabular}

$E$ After the course on entrepreneurship: In response to the query about what will they do after finishing MBA, 78\% of the respondents said they would find a job and $22 \%$ responded that they would start a business. So the majority preferred job over entrepreneurship. Table No. 6 shows career choice of respondents after MBA

Table No. 6 Career Choice after MBA

\begin{tabular}{|l|l|l|}
\hline Response & Frequency & Percentage \\
\hline Find a job & 124 & 78 \\
\hline Start Business & 36 & 22 \\
\hline Higher Studies & 0 & 0 \\
\hline $\begin{array}{l}\text { Join family } \\
\text { business }\end{array}$ & 0 & 0 \\
\hline Others & 0 & 0 \\
\hline Total & 160 & 100 \\
\hline
\end{tabular}

Regarding period of starting the business, $12 \%$ had responded that they would start immediately after finishing MBA, $12 \%$ after 6

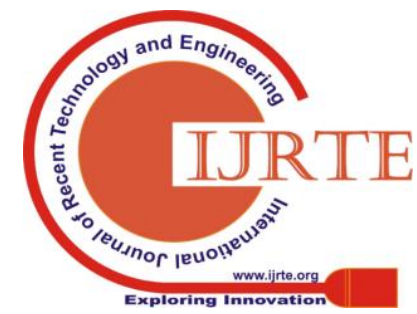


months, $8 \%$ after 2 years and $68 \%$ would start after more than two years. Table No. 7 displays the period by which the respondents would start a business if given a chance.

Table No. 7 Period of starting business

\begin{tabular}{|l|l|l|}
\hline Response & Frequency & Percentage \\
\hline $\begin{array}{l}\text { Immediately after } \\
\text { MBA }\end{array}$ & 12 & 12 \\
\hline After 6 months & 12 & 12 \\
\hline After 1 year & 0 & 0 \\
\hline After 2 years & 8 & 8 \\
\hline More than 2 years & 68 & 68 \\
\hline Total & 100 & 100 \\
\hline
\end{tabular}

Regarding the main traits of entrepreneurship, 77\% had responded that they can make their own decisions, $78 \%$ can find solutions to problems, $60 \%$ can take calculated risks, $87 \%$ constantly tried to improve the way they work or study. $85 \%$ required further training on the subject entrepreneurship, $85 \%$ were ready to recommend this course to others.

F Hypothesis Testing: Three hypothesis were tested. Hypothesis-1 found out whether there is significant relationship between gender and entrepreneurial intension. $27 \%$ of the male students had responded that they will start a business after the course. $29 \%$ of the female respondents also had shown their intention to start enterprise. This shows not much difference in genders regarding entrepreneurial intent. The chi-square test conducted had given a calculated value of 0.0318 and a table value (at $5 \%$ significance level) of 9.488 . Since the calculated value is less than the table value, the Hypothesis (H0) is accepted. So, there was no significant difference between male and female in their entrepreneurial intensions.

Table No. 8 Showing Gender Vs Entrepreneurial Intention

\begin{tabular}{|l|l|l|l|l|l|l|}
\hline $\begin{array}{l}\text { Gend } \\
\text { er }\end{array}$ & job & $\begin{array}{l}\text { busin } \\
\text { ess }\end{array}$ & $\begin{array}{l}\text { High } \\
\text { er } \\
\text { studi }\end{array}$ & $\begin{array}{l}\text { Family } \\
\text { busine }\end{array}$ & $\begin{array}{l}\text { Othe } \\
\text { rs }\end{array}$ & $\begin{array}{l}\text { Tot } \\
\text { al }\end{array}$ \\
\hline
\end{tabular}

Retrieval Number: B10760782S419/2019@BEIESP DOI: 10.35940/ijrte.B1076.0782S419

\begin{tabular}{|l|l|l|l|l|l|l|}
\hline & & & es & ss & & \\
\hline Male & 32 & 12 & 0 & 0 & 0 & 44 \\
\hline $\begin{array}{l}\text { Fema } \\
\text { le }\end{array}$ & 80 & 32 & 0 & 0 & 0 & 112 \\
\hline Total & 112 & 44 & 0 & 0 & 0 & 156 \\
\hline
\end{tabular}

Hypothesis-II found out whether there is significant relationship between gender and risk taking ability, which was an indicator of entrepreneurship. $78 \%$ of the male respondents had agreed that they were willing to take risks while only $58 \%$ of the female respondents were ready to take risks. This shows that there is significant difference between genders in risk taking ability. Chi-square test revealed that the calculated value of 19.04 was greater than the table value (at 5\% significance level) of 9.488 and hence the $\mathrm{HO}$ is rejected and $\mathrm{H} 1$ accepted. That is there is significant difference between males and females in their risk taking ability. Females are averse to take risk as compared to males. Table No. 9 Shows the cross tabulation.

Table No. 9 Showing Gender Vs Risk Taking Ability

\begin{tabular}{|l|l|l|l|l|l|l|}
\hline Gender & $\begin{array}{l}\text { Stro } \\
\text { ngly } \\
\text { Agr } \\
\text { ee }\end{array}$ & Agree & $\begin{array}{l}\text { Neutr } \\
\text { al }\end{array}$ & $\begin{array}{l}\text { Disag } \\
\text { ree }\end{array}$ & $\begin{array}{l}\text { Stron } \\
\text { gly } \\
\text { Disag } \\
\text { ree }\end{array}$ & Total \\
\hline Male & 16 & 12 & 0 & 8 & 0 & 36 \\
\hline Female & 20 & 36 & 36 & 4 & 0 & 96 \\
\hline Total & 36 & 48 & 36 & 12 & 0 & 132 \\
\hline
\end{tabular}

Hypothesis III: To find whether there is any significant relationship between the Occupation of the parent and entrepreneurial intention of the child. Only $20 \%$ of the children of parents with business had shown interest in starting business. The percentage of respondents who were interested in starting business after MBA were $23 \%$ in case of self-employed parents and $21 \%$ in the case of employed parents. The Chi-square test had shown that the calculated value of 6.865 was less than the table value (5\% significance) of 21.026, the null hypothesis is accepted. That meant there was no significant relation between parents' occupation and entrepreneurial intention of the child. Table No. 10 shows the cross tabulation.

Table No.10 Showing Occupation of the parent Vs entrepreneurial intention of the Child

Published By:

Blue Eyes Intelligence Engineering \& Sciences Publication

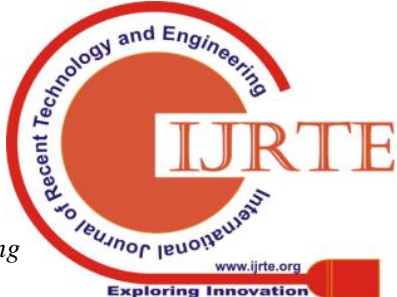


Effect of Entrepreneurship Education on MBA students in Kerala on their entrepreneurial intent with special reference to the students of Mahatma Gandhi University, Kottayam, Kerala

\begin{tabular}{|l|l|l|l|l|l|l|}
\hline $\begin{array}{l}\text { Occupat } \\
\text { ion of } \\
\text { Parent }\end{array}$ & Job & $\begin{array}{l}\text { Sta } \\
\text { rt } \\
\text { bus } \\
\text { ine } \\
\text { ss }\end{array}$ & $\begin{array}{l}\text { High } \\
\text { er } \\
\text { studi } \\
\text { es }\end{array}$ & $\begin{array}{l}\text { Famil } \\
\text { busin } \\
\text { ess }\end{array}$ & $\begin{array}{l}\text { Othe } \\
\text { rs }\end{array}$ & $\begin{array}{l}\text { Tot } \\
\text { al }\end{array}$ \\
\hline Job & 44 & 12 & 0 & 0 & 0 & 56 \\
\hline $\begin{array}{l}\text { Self-em } \\
\text { ployed }\end{array}$ & 40 & 12 & 0 & 0 & 0 & 52 \\
\hline $\begin{array}{l}\text { Own } \\
\text { business }\end{array}$ & 32 & 8 & 0 & 0 & 0 & 40 \\
\hline Others & 8 & 0 & 0 & 0 & 0 & 8 \\
\hline Total & 124 & 32 & 0 & 0 & 0 & 156 \\
\hline
\end{tabular}

$G$ Open ended question/suggestion by respondents: Less than half of the respondents had answered the open-ended question with suggestions. Many were of the view that present syllabus need updating and industry relevant topics needed to be added.

Some suggested that latest teaching methods like experiential learning should be included. Some respondents needed more practical sessions and workshops. More industrial visits and interactions with start-ups were suggested by some respondents. Others needed good course materials and more training hours on entrepreneurship

\section{FINDINGS}

Following were some of the major findings of the study

There was no difference in entrepreneurial intention of the students after the course on entrepreneurship. Before joining the MBA $22 \%$ had responded that they wanted to start a business or join family business. But, after the course on entrepreneurship also, the percentage of MBA students who opt for entrepreneurship remained same. High paying job remained the most popular choice after MBA for the students. Actually, the choice had increased marginally from $75 \%$ during pre-MBA time to $78 \%$ after MBA.

If given an option to start a business, only $12 \%$ were willing to start immediately after MBA and another $12 \%$ after 6 months of finishing MBA again validating the above findings. The Majority (76\%) wanted to postpone starting after two or more years. This clearly shows their reluctance to start a business. This may be because they get campus placements in the $4^{\text {th }}$ semester of MBA with a higher average salary than other professional courses.

Even though many of them were reluctant to start the business, the entrepreneurship course had increased their personality traits like risk taking, problem solving skills, decision making skills, quality awareness etc. which would help them to advance in their future career as well as in any future venture.

Three hypothesis were tested. Regarding relationship between gender and entrepreneurial Intention, the null hypothesis was accepted. That meant, there was no significant difference between males and female in their intention to start a business. But, in the second test about relationship between gender and risk taking, the alternate hypothesis was accepted. Here, there was significant difference between males and females in their risk taking ability. Males were more prone to take risks. In the third test, the null hypothesis was accepted. That meant there was no significant relationship between occupation of the parent and the entrepreneurial intention of the child. That means the parent's business background is not affecting the child's intention to start a business.

\section{CONCLUSION}

Thus the study has found that the MBA students of Kerala prefer a high paying job instead of a high achieving business. There are many reasons for this main one being the risk aversion of the female students. Even though the male students are more ready to take risk, they prefer a job initially. The current entrepreneurship course offered to MBA students are inadequate to create entrepreneurial interest in them. More innovative methods of teaching like experiential learning, simulation, mentoring etc. can be tried. Training can be planned to promote creativity, innovation in students and they shall be encouraged to take calculated risks.

\section{References}

1. Ahluvalia, M. S., 2005. India's economic reforms: An appraisal Government of India: papers of the Planning Commission of India.

2. Barot, D. H., 2015. Entrepreneurship - A Key to Success. THE INTERNATIONAL JOURNAL OF BUSINESS \& MANAGEMENT

3. Basu, R., 2014. Entrepreneurship Education in India: A Critica Assessment and a Proposed Framework. Technology Innovation Management Review, pp. 5-10.

4. Carvalho, P. M. C. D. a. L. M. C., 2009. CASE STUDY: Promoting business creation through real world experience; Projecto Comec, ar. Education + Training, pp. 150-169

5. David Rae, N. R. W.-H., 2013. How does enterprise and entrepreneurship education influence postgraduate students' career intentions in theNew Era economy?. Education + Training, pp. 926-948.

6. David Rae, N. W.-H., 2012. International entrepreneurship education: Postgraduate business student experiences of entrepreneurship education. Education + Training, pp. 639-656.

7. Gary Packham, P. J. C. M. D. P. a. B. T., 2010. Attitudes towards entrepreneurship education: a comparative analysis. Education + Training, pp. 568-586.

8. Gerba, D. T., 2012. Measure for Measure: Modeling Entrepreneurial Self-Efficacy onto Instrumental Tasks

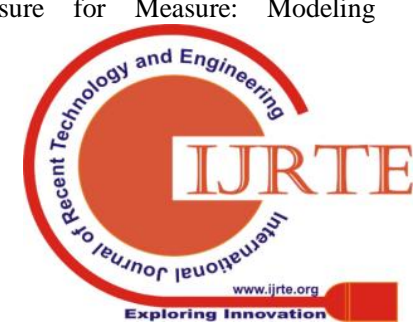


Within the New Venture Creation Process. Management Research Review, pp. 225-244.

9. Hegarty, C., 2006. It's not an exact science: teaching entrepreneurship in Northern Ireland. Education + Training, pp. 322-335.

10. K.G.Chandrika, 2012. Entrepreneurship through Apprenticeship A Case Study. Drishtikon: A Management Journal, pp. 194- 205.

11. Paul Jones, A. J. G. P. a. C. M., 2008. Student attitudes towards enterprise education in Poland: a positive impact. Education + Training, pp. 597-614.

12. Purna Prabhakar Nandamuri, R. K. G., 2012. A Strategic Analysis of Entrepreneurial Orientation of Management Graduates. The IUP Journal of Business Strategy, pp. 7- 23.

13. Rejab, M. N. Z. a. M. R. M., 2010. Assessing "ME generation's" entrepreneurship degree programmes in Malaysia. Education + Training, pp. 508-527.

14. Sahasranam, S. A. V. K. a. C., 2009. Entrepreneurial Characteristics Among Business Management Students: An Empirical Study. The IUP Journal of Management Research, pp. 7-29.

15. University, M., 2017. MBA Syllabus, Kottayam: MG University.

16. Zainalabidin Mohamed, G. R. M. N. S. a. M. M. M., 2012. Enhancing young graduates' intention towards entrepreneurship development in Malaysia. Education + Training, pp. 605-618.
Published By: Blue Eyes Intelligence Engineering \& Sciences Publication

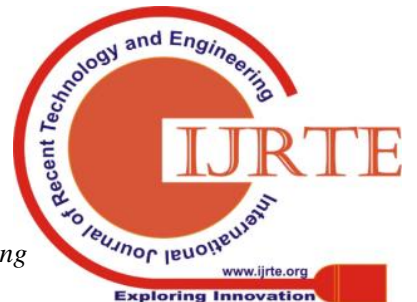

